HUNGARIAN AGRICULTURAL ENGINEERING

$N^{\circ} 26 / 2014$ 47-53

Published online: http://hae-journals.org/

HU ISSN 0864-7410 (Print) / HU ISSN 2415-9751(Online)

DOI: 10.17676/HAE.2014.26.47
PERIODICAL OF THE COMITTEE OF AGRICULTURAL AND BIOSYSTEM ENGINEERING OF THE HUNGARIAN ACADEMY OF SCIENCES and SZENT ISTVÁN UNIVERSITY

Faculty of Mechanical Engineering

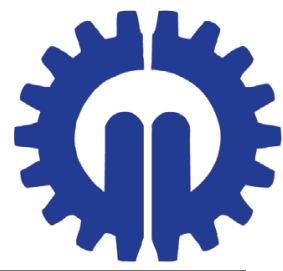

\title{
COMPARISON OF POSSIBLE GREENHOUSE ENERGY SOURCES
}

Author(s):

J. Nagygál ${ }^{1}$, L. Tóth ${ }^{1}$, J.Beke ${ }^{1}$, I. Szabó ${ }^{2}$

Affiliation:

Szent Isván University, Hungary, 2100 Gödöllö, Páter K. u. 1.

${ }^{1}$ Institute of Process Engineering, ${ }^{2}$ Institute of Mechanics and Machinery

Email address:

nagygj@arpad.hu, toth.laszlo@gek.szie.hu, beke.janos@gek.szie.hu, szabo.istvan@gek.szie.hu

\begin{abstract}
The most prominent cost of a greenhouse is the energy consumption, meaning that when planning systems, analysing the energy-efficiency of the method to be used, and its results is one of the most important factors. The heat resource depends on the heating system, and indirectly on the technological implementation of production. Overall, the most cost-effective solution with the least amount of losses can be one specific course of planning, while another can be the performance and the relative age of the system, which would mean a higher cost. We can't disregard planning for the future changes in resource price (if there is a change).
\end{abstract}

\section{Keywords}

greenhouse, heating energy, greenhouses specific energy consumption

\section{Introduction}

Producing energy supply of greenhouses, and usable energy resources

Nowadays, building greenhouses is at its renaissance. The modern, high atmosphere greenhouses create a huge advancement for the sector due to the most recent building techniques, and the most proficient engineering solutions. In Hungary, greenhouses can only operate with a profit for a limited time interval, in the era of borderless, open trade. This time interval of a few months is between the rush of unheated greenhouses of South-western Europe and Northern Africa, and the rush of domestic open-air plant production and unheated greenhouses. This technically falls between December-January and May [3, 14, 17, 18]. These months cover most of the heating season of winter, meaning plant production in winter isn't possible without heating the greenhouses. We have a multitude of possible energy sources to cover this, but domestic practice and the development resources of horticultures, not to mention their low profitability, caused only a few to be widespread. [19].

\section{Source and method}

Energy sources in widest use [25]:

Heat production using combustion:

-Firewood, wood chips [13]

-Pelletized heat sources

- Coal

- Natural gas or LP gas

-Fuel oil / Crude oil

Without combustion [9, 20]:

-Heat withdrawal using thermal water.

Using supporting energy sources (electric energy, natural gas, pyrolisis gas) using environmental heat [15, 16,]:

-Heat-pumps (air-air, ground-air, or wastewater-air)

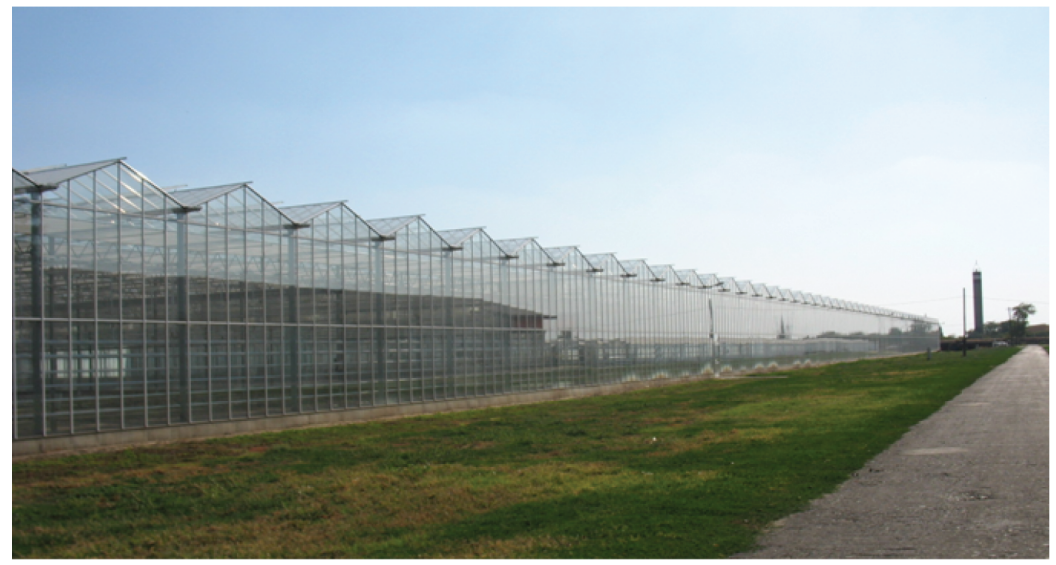

Figure 1. Modern, high atmosphere greenhouse in Southern Hungary 
In Hungary, all energy resources are available, and the best solution fully depends on how economic its use is [11, 21]. We hope that the next introductions help with choosing a solution, seeing that the data is double-checked, and up-to-date, as much as possible.

The life expectancy of the machinery is not set in stone, but during the calculations, we found it rational to use a 15 year lifecycle. The requirement was set to be $1600 \mathrm{~kW}$, since this is relatively close to the planned energy requirements of greenhouses with huge internal space, equipped with double-glass plating, greenhouse shades and ground-, vegetation- and shoottip heating, with a 5-5,5 m furrow height, and $10.000 \mathrm{~m} 2$ floor area. If we consider the weather conditions of the last few years, the heat requirement of an intensively cultivated 1,0ha greenhouse is around $300-320 \mathrm{kWh} / \mathrm{m} 2$ each year (Figure 1.).

Defining heat requirement 22]:

The widely used equation for heat requirement is as follows [6,

$$
\begin{array}{ll}
\multicolumn{1}{c}{\mathrm{Q}=\mathrm{K}^{\prime}(\mathrm{tb}-\mathrm{tk}) \mathrm{Fü}} \\
\text { where: } & \begin{array}{l}
\text { amount of heat needed each hour }(\mathrm{kJ} / \mathrm{h}) \\
\mathrm{Q}=
\end{array} \\
\mathrm{K}^{\prime}= & \begin{array}{l}
\text {,heat consumption" coefficient }\left(\mathrm{kJ} / \mathrm{m}^{2} \mathrm{~h}^{\circ} \mathrm{C}\right) \\
\mathrm{tb}-\mathrm{tk}=\Delta \mathrm{t}=\begin{array}{l}
\text { difference between outer and inner heat } \\
\text { requirement }\left({ }^{\circ} \mathrm{C}\right) \\
\text { the surface area of the greenhouse in question } \\
\left(\mathrm{m}^{2}\right)
\end{array}
\end{array} \\
\mathrm{Fü}= &
\end{array}
$$

\section{Firewood, wood chips}

If we look at the heating of greenhouses in the last few years, wood has become more and more widely used. The wood here means mostly the wood, and its scobs from deciduous forests, and wood unusable for either building or crafting, and the trimmings and liber of wood used in the building industry $[5,13,24]$.

Pros:

Easily acquirable, both in log and in wood chip forms. Its price didn't have a substantial change in recent years, calculations with heating costs are therefore easier, meaning we can do an easily definable cost-calculation. The price of furnaces is usually costaccomodating, their build is relatively simple, and can be found in a wide range on markets. In recent years, industrial wood- and chip furnaces can abide by nature conservation regulations due to recent developments appearing on the market. The resources are essentially renewable sources, given the defined logging circumstances, meaning their subsidy may be imminent [4].

Cons:

May have costs and risks due to the usually huge transport distances. The appearance of tolls make its transportation even more expensive. The mass/volume and calorific value/volume ratios are low. Obtaining dry resource at a low price is rare, since in the last 10 years, using firewood also lives its renaissance for the general populace, meaning the demand on the market varies by time. This can be lessened with importing logs in truck volume. Its effective combustion in a furnace is hard to automate, due to its inherent need for human overseeing.

\section{Pelletized material}

Became more popular in recent years. Fibrous material made using high pressure, which is coagulated by either an outside coagulant, or its own material. Pelletized material can range from a few millimetres to a few centimetres, depending on what pelletizing technology was used to create it.

Pros:

Pelletized material can be easily acquired, and in many quality variations, depending on calorific volume. The standardized size (length and girth) makes its combustion easily automatable. Its price depends on materials used, and relatively stable, if we look at recent prices, without bigger deviations, meaning the cost of heating is easily calculated. The prices of furnaces, similar to wood furnaces, is relatively favourable. Pelletized material is treated as a renewable source. Due to the production technology, its hydration is low.

Cons:

Making pelletized material demands high amounts of energy, mostly due to the performance and high consumption of pelletizing machinery, which makes an impact on the energy balance of utilization. Its transport fees are high, since it's mostly vehicular transport, which requires robust vehicles due to its high capacity requirement. Since the pelletized material needed for the entire production season must also be stored, the loading and storehouse costs are further problems. Some base materials make the nature conservation regulations hard to follow, and the sludge in the furnaces may cause malfunctions.

\section{Lignite, coal}

Pros:

Due to the developments of the market in recent decades, the coal reserves can be called "abundant". According to the plans of the government, we can expect the re-opening of multiple coalmines. Thanks to the research of recent years, and the appearance of socalled "clean" coal technologies, the nature conservation level, and the assessment of efficiency took a turn for the better.

Its price is stabile, since the market is more focused on supply, meaning the acquisition doesn't pose a problem. Its transport fees can be lowered substantially due to the classic railway-transport. The price of furnaces is extremely favourable in its category.

Cons:

If the area of usage is far from the railway, the vehicular transport will add to the costs of usage. Automating is hard, technically requires human intervention at all times, therefore, the needs of actual labour are high in comparison. Heating can't be regulated well, reaction to changing heat needs comes with a relatively low hysteresis, meaning buffer heat capacitors are needed for the system to be applicable to greenhouse heating.

\section{Natural gas or LP gas}

Natural gas is a mixture of carbon-hydrogen-based gases, and is highly flammable. Its main elements are methane, ethane, propane, and butane. The canned gas, or LP gas is fluidic gas which mainly consists of either propane, butane, or a propanebutane mixture.

Pros:

Since the chemical composition of fluidic gas is relatively simple, it's the cleanest, and has the highest calorific volume of all alternative resources. The system can be automated perfectly, offers a clean factory, while the furnaces are modern and easily calibrated and regulated, meaning it's an overall flexible heating method. Another extra benefit in case of greenhouses during the winter season is the carbon-dioxide collection, which can be rerouted to the plants, which lowers costs and has a positive impact on production yield. The close availability of piped gas makes connecting to the heat source easy, and simplifies the planning-implementation procedure. The installation of LP gas can be solved with a low cost, its planning and implementation is a simple task.

Cons:

The purchase and acquisition of natural and LP gas is frequently the target of the political happenings and manipulation of various countries. Since in Hungary, the first thing we have to 
consider is import - due to our domestic reserves being insufficient to cover needs - it's difficult to determine the costs of the gas industry several decades ahead. In most horticultures, piped gas isn't acquirable, and the necessary building costs are huge, and if we include the licensing, the registry of easements in light of the dispersion of land rights, it seems outright impossible. The price of LP gas increased drastically in recent years, making the horticultures fully dependent on gas heating impossible to manage.

\section{Fuel oil}

Oil in itself contains a multitude of various organic compounds. These are not extracted in their clear state, but instead divided by their area of use. One of these is fuel oil.

Pros:

The system can be easily automated, and offers a clean factory if the implemented machinery is modern, the furnaces are welldeveloped, easily regulated, and it's an overall flexible heating method. The cost to install it is low, the price of furnaces is acceptable. The system can be booted quickly, meaning it's best used as extra (supplementary) or emergency heating.

Cons:

The global market price of oil shows quite a hectic change every now and then, meaning it's difficult to plan for decades, resulting in an also difficult cost calculation. Storing oil is in itself a hardship, and while vehicular transport is an option, transport fees are high. Also, it isn't renewable as an energy resource.

\section{Thermal water}

In Hungary, it's the most easily procurable, and easy to excavate source of soil heat. Soil heat is the inner heat of the ground, which is born mainly from the heat of radioactive isotopes, and the friction heat of convectional flow (Figure 2).

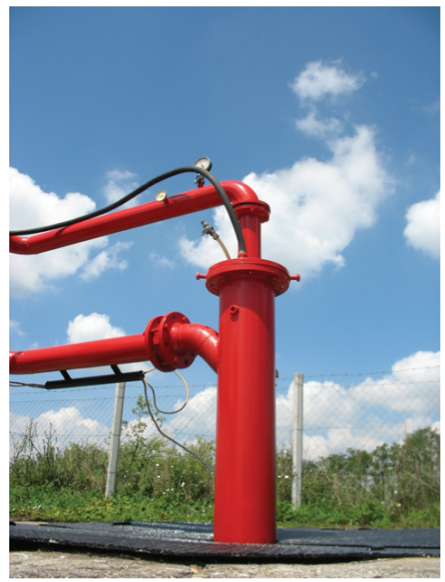

Figure 2. Thermal well with diving-pump excavation

Pros:

Thermal water adequately transports and radiates heat without any form of conversion, either in a direct, or in an indirect fashion. The operational costs of a thermal well are relatively low, in comparison to the energy excavated, meaning the heating based on thermal water is competitive. On Hungary's horticultural lands - mainly lowland - it's almost always present (Figure 3.). A locally found heat resource, needs no transport or import, does not depend on either season, time of day, or weather. The system can be automated easily, but only with a buffer tank which is the right size. The soil heat excavated is a renewable source, while the excavated water is partially renewable, depending on how the reserves refill $[12,19,23]$.

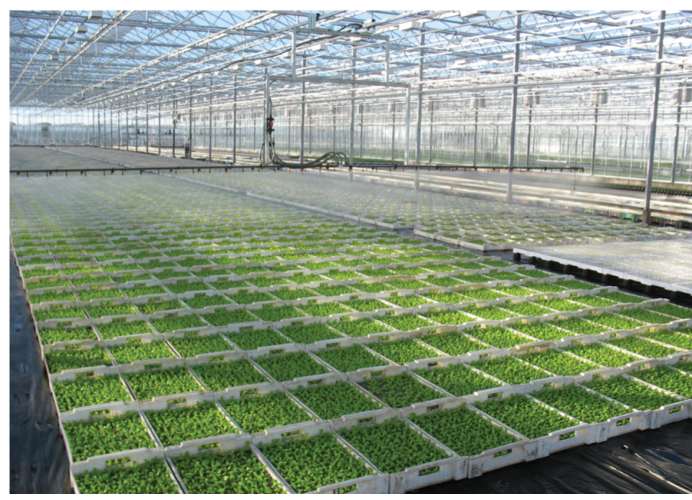

Figure 3. Greenhouse plant production using thermal water heating in January

Cons:

Boring a thermal well is costly. The piping of the water, and its transportation to the area of usage sometimes requires the installation of high-level infrastructure. It's not available everywhere, and the water is not always adequate for excavation. Water placement is a problem which has been resurfacing for decades - placement above ground, or refilling? The system's long-term operation, and the maintenance of the wells can only be done with a slow hysteresis, otherwise, malfunction is inevitable. The basic requirement of this method is the big buffer tank, which costs a lot to install. Excavation and wiring requires electricity. The placement above ground raises enviro-protection questions in case of high salt concentration water. Similarly, refilling raises drinking water-base questions, when it's done to a layer more shallow than the source.

\section{Heat-pump}

Heat-pumps are machines - caloric machines - that are used to extract heat from a lower temperature environment, and transport it to a higher temperature area. The goal of its usage is to manage heat energy, during which cooling energy can be used for heating purposes (f.e. water-heating), and the heat of the environment can be exploited. Heat-pumps are essentially cooling machines, which implement the transmitted heat on the hot side, instead of the extracted heat on the cool side $[8,1]$.

Pros:

The machinery went through a drastic evolution in the last century, and has a much better efficiency rate. In terms of drive, it can be either electric, or engine-driven. The mass used for heat extraction can be air, ground (probe or collector), and subterranean water, or even leachate. In itself, it can be used as either main or supplementary heating. It's easy to control, and using well-defined heat levels, can be very efficient. When using supplementary energy, it generates the heat return three- to fourfold. It's a dependable machine, and requires light maintenance. Cons:

Installing and maintaining it requires a high level of attention and professional skill. In case of a high requirement of heat energy, we have to calculate with high electricity needs. The useful medium-temperature is limited efficiency-wise. Installing it is relatively expensive.

\section{Economic analysis}

Installation prices of systems, and prices of specific energy Since the heating requirement can vary between landscapes due to external effects, the values in Charts 1,2, and 3 can't be used universally for each area, and therefore offer comparisons. 
In Chart 2, we used average prices for industrial users in Hungary when we defined the prices of energy sources. When we defined the prices of the machinery, we aimed to select the ones with high quality, and good price/performance ratio. Since we can find the products of many manufacturers on the market, from cheap to premium categories at that, we selected the prices of a Hungarian manufacturer which has both a marketing- and a service chain. We used the price of a Hungarian well-borer as a basis for thermal well-boring, who has references.

During the calculation of operation costs, we also included the taxes and fines that come with the system's usage. We chose a legal, approved, and completely regulation-abiding operation methods for each energy production method. Prices include the enviro-protection and enviro-pressure fees as well. At this point, we have to resolve a contradiction. Some of the enviro-protection fees in Hungary are fines by default, while in Western-European practice, activities which are fined must be discontinued. This is the reason that our naming could prove misleading in international comparison, it may raise questions, and cause conflicts, since we count an enviro-pressure fine a tax-like cost. In Hungary, winter plant production means a 30 Co heat level $(\Delta t)$. In Hungary, winter plant production means a 30 Co heat level $(\Delta t)$. The growing costs of fossilized energy resources result in geothermal energy with efficient use becoming more competitive for winter heating.

In the end, we defined the costs of each system at $1600 \mathrm{~kW}$ heat performance requirement using the data from designers and operators, and the offers seen on the internet (Chart 1). We calculated the fuel prices similarly (Chart 2).

Chart 1 . Install costs of systems

\begin{tabular}{|l|c|c|c|}
\hline & Install cost & Life expectancy & $\begin{array}{c}\text { Annual cost derived } \\
\text { from life expectancy }\end{array}$ \\
\hline & {$[\mathrm{HUF}]$} & {$[$ year] } & {$[$ HUF/year] } \\
\hline Firewood boiler & 26500000 & 20 & 1325000 \\
\hline Pellet boiler & 25000000 & 15 & 1666667 \\
\hline Lignite boiler & 15000000 & 20 & 750000 \\
\hline Coal boiler & 15000000 & 20 & 750000 \\
\hline Gas boiler & 7500000 & 25 & 300000 \\
\hline Oil boiler & 18000000 & 20 & 900000 \\
\hline Thermal well & 145000000 & 40 & 3625000 \\
\hline Heat-pump (electric) & 128000000 & 25 & 5120000 \\
\hline
\end{tabular}

Chart 2. Unit price and actual energy which can be extracted

\begin{tabular}{|l|c|c|c|c|}
\hline & $\begin{array}{c}\text { Calorific value } \\
\text { and energy by } \\
\text { unit }\end{array}$ & $\begin{array}{c}\text { Price of } \\
\text { resource by } \\
\text { unit }\end{array}$ & $\begin{array}{c}\text { Efficiency of } \\
\text { transformation }\end{array}$ & $\begin{array}{c}\text { Actual energy } \\
\text { extracted }\end{array}$ \\
\hline Firewood & $4,0-4,4 \mathrm{kWh} / \mathrm{kg}$ & $45 \mathrm{HUF} / \mathrm{kg}$ & $75 \%$ & $3-3,3 \mathrm{kWh} / \mathrm{kg}$ \\
\hline Pellet & $5 \mathrm{kWh} / \mathrm{kg}$ & $75 \mathrm{HUF} / \mathrm{kg}$ & $75 \%$ & $3,75 \mathrm{kWh} / \mathrm{kg}$ \\
\hline Lignite & $5,6 \mathrm{kWh} / \mathrm{kg}$ & $54 \mathrm{HUF} / \mathrm{kg}$ & $85 \%$ & $4,76 \mathrm{kWh} / \mathrm{kg}$ \\
\hline Coal & $8,2 \mathrm{kWh} / \mathrm{kg}$ & $63 \mathrm{HUF} / \mathrm{kg}$ & $85 \%$ & $6,97 \mathrm{kWh} / \mathrm{kg}$ \\
\hline Gas & $9,7-12,5 \mathrm{kWh} / \mathrm{m}^{3}$ & $135 \mathrm{HUF} / \mathrm{m} 3$ & $94 \%$ & $\begin{array}{c}9,12-11,75 \\
\mathrm{kWh} / \mathrm{m}^{3}\end{array}$ \\
\hline Oil & $11,1 \mathrm{kWh} / \mathrm{kg}$ & $330 \mathrm{HUF} / \mathrm{kg}$ & $92 \%$ & $10,2 \mathrm{kWh} / \mathrm{kg}$ \\
\hline Thermal water & $\begin{array}{c}0,06 \mathrm{kWh} / \mathrm{kg} \\
(\mathrm{dt}=85 / 30)\end{array}$ & $\begin{array}{c}0,0247 \\
\mathrm{HUF} / \mathrm{kg}\end{array}$ & None & None \\
\hline Heat-pump (air) & $1 \mathrm{kWh} / \mathrm{kWh}$ & $\begin{array}{c}35-45 \\
\text { HUF/kWh }\end{array}$ & COP 3,5-4 & $\begin{array}{c}3,5-4,0 \\
\mathrm{kWh} / \mathrm{kWh}\end{array}$ \\
\hline Heat-pump (soil) & $1 \mathrm{kWh} / \mathrm{kWh}$ & $\begin{array}{c}35-45 \\
\text { HUF } / \mathrm{kWh}\end{array}$ & COP $5-6$ & $5-6 \mathrm{kWh} / \mathrm{kWh}$ \\
\hline
\end{tabular}

Chart 3. Specific cost, and annual energy cost

\begin{tabular}{|l|c|c|c|}
\hline & $\begin{array}{c}\text { Annual cost for } \\
\text { the system's } \\
\text { return in 15 years }\end{array}$ & $\begin{array}{c}1 \mathrm{kWh} \\
\text { heat's } \\
\text { resource } \\
\text { cost }\end{array}$ & $\begin{array}{c}\text { Annual energy } \\
\text { cost (resource }+ \\
\text { machinery) for a } \\
\text { return in 15 years }\end{array}$ \\
\hline Firewood boiler & 1767000 & 15 & 88167000 \\
\hline Pellet boiler & 1667000 & 20 & 116867000 \\
\hline Lignite boiler & 1000000 & 11,3 & 66318400 \\
\hline Coal boiler & 1000000 & 9 & 53012800 \\
\hline Gas boiler & 500000 & 14,8 & 85748000 \\
\hline Oil boiler & 1200000 & 32,4 & 187536000 \\
\hline Thermal well & 9667000 & 0,4 & 12028600 \\
\hline Heat-pump (electric) & 8534000 & 12,8 & 82262000 \\
\hline
\end{tabular}




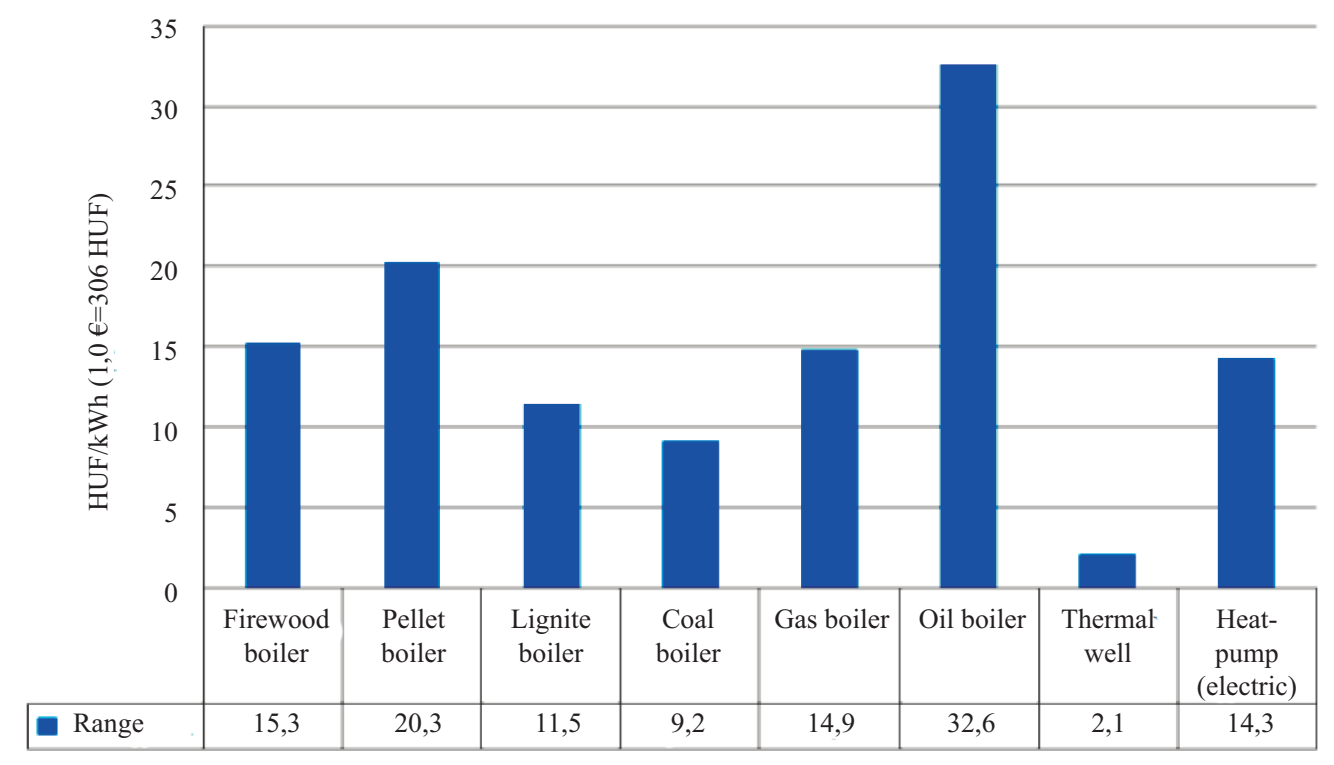

Figure 4. The total cost of $1,0 \mathrm{kWh}$ heat for the system's return in 15 years.

As we can see on the data of the diagram (Illustration 2), the most cost-efficient is the thermal well heating system, followed by the coal- and lignite heating systems, and the heat-pump system is only fourth. The calculations are correct for the given situation, but the heat-pump systems have further benefits, which we will introduce later on. Before we elaborate, we have to mention that the thermal water system is the simplest type (see: Illustration 1, var. A).

\section{Results and discussion}

\section{Thermal water system, and its heat-pumping}

As we already mentioned, the above ground placement of thermal water (Figure 5, and 6. var. B) raises enviro-protection concerns due to its high concentration of salt (which is the reason it's subjected to an enviro-pressure fine). The refilling into thermal wells (Illustration 6. var. B) raises drinking water-base problems, in case of more shallow layers. However, in spite of this, using it is necessary for sustainability reasons. Another option is to extract the thermal energy from the high-enthalpy fluid before refilling it (Figure 6. var. C) $[1,2]$.

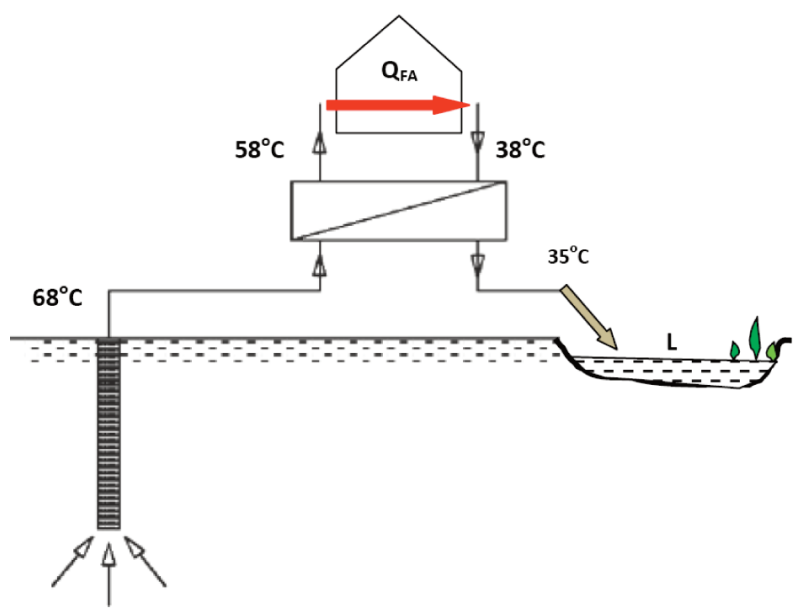

Figure 5. The traditional method of using thermal $(\mathrm{L}=$ lake or river)

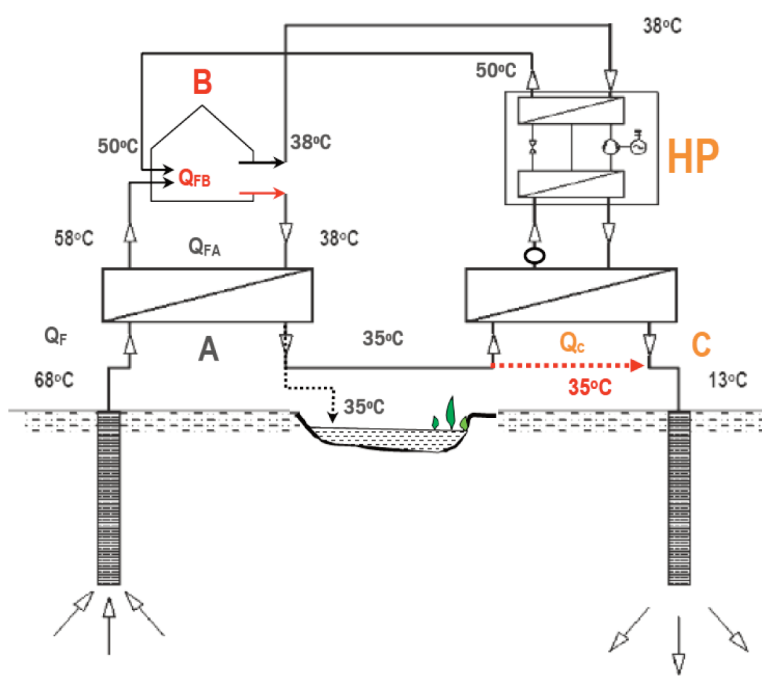

Figure 6. Usage options of thermal water

$\mathrm{A}=$ Direct heating using thermal water right from the source, and re-routing the cooled $\left(25-35^{\circ} \mathrm{C}\right)$ water to a resting lake, or river after intensive dilution

$\mathrm{B}=$ Leading thermal water right from the source into a heat-changer (QFA) and refilling the water cooled due to extracted heat $\left(\sim 35-40^{\circ} \mathrm{C}\right)$

$\mathrm{C}=$ Leading thermal water right from the source into a heat-changer $(\mathrm{QFA})$ and leading the water cooled due to extracted heat $\left(\sim 35-40{ }^{\circ} \mathrm{C}\right)$ into another heatchanger $(\mathrm{Qc})$, heat-pumping it, then refilling the cooled water (10-13 Co), and rerouting the heat into the heating system

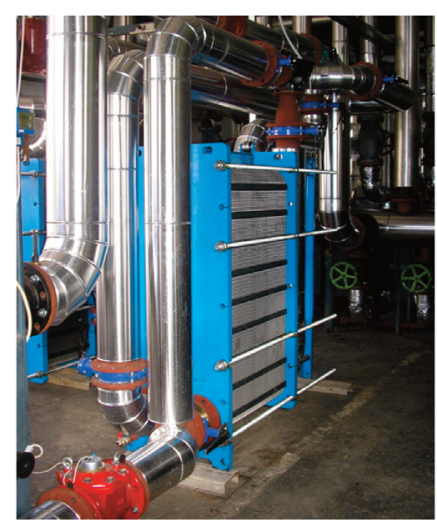

Figure 7. Heat changers before the heating circulation 
The heat extractable using the heat-pumps depends on the mass flow (Figure 7.), and the $\Delta \mathrm{T}$ (in- and outbound fluid temperature difference):

A

$$
Q_{F A}=\dot{m} c\left(T_{68}-T_{35}\right)
$$

$$
Q_{F B}=\dot{m} c\left(T_{50}-T_{38}\right) \quad[\mathrm{kW}]
$$

$\mathrm{C}$ (using heat pump)

$$
Q_{F C}=\dot{m} c\left(T_{35}-T_{13}\right) \frac{\varepsilon_{f}}{\varepsilon_{f}-1}
$$

$\mathrm{B}$ and $\mathrm{C}$

$$
Q_{F(C-B)}=Q_{F B}+Q_{F C} \quad[\mathrm{~kW}]
$$

The heat extraction processes can be defined by thermodynamic methods. As an example, we use the so-called T diagram to show the thermo-dynamic average heat of the heat extracted with the heat-pump, and the temperature of regression (Figure 8). The average temperature is derived from the higher inbound, and the lower outbound temperatures. It's practically defined by the mid-temperature of the logarithm [7].

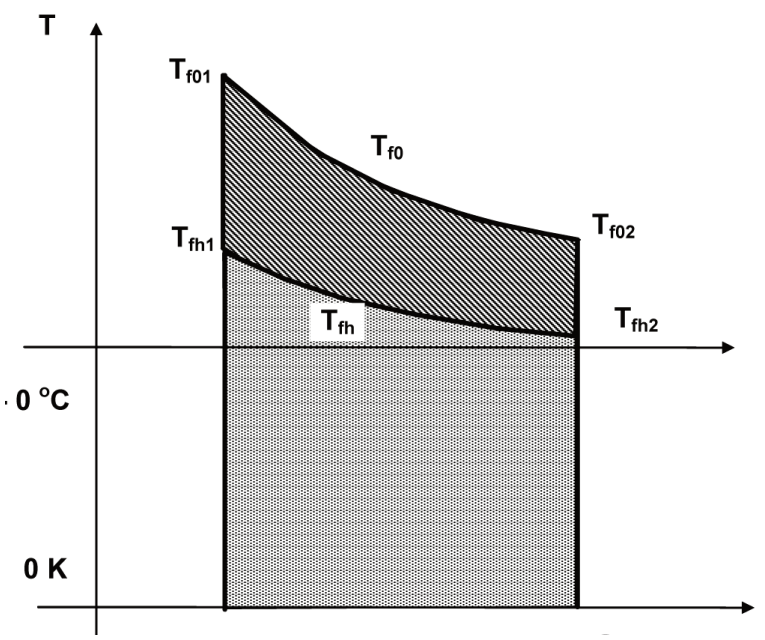

Figure 8 . How the heat-pump works, shown on the T diagram

Using the thermo-dynamic average temperature, we can define the so-called "correctness factor" of heat-pumping ( $\varepsilon$, and COP). $\varepsilon$ is actually a hypothetical factor derived from T-S.

The average temperature of the heat delivered on the heat changer's hot side (vaporizer) and the heating side (condenser) using heat-pump:

Heat radiating side based on the T-S diagram:

$$
\overline{T_{f o}}=\frac{\bar{T}_{f 01}-\bar{T}_{f 02}}{\ln \frac{\bar{T}_{f 01}}{\bar{T}_{f 02}}}
$$

And the heat absorbing side:

$$
\overline{T_{f h}}=\frac{\bar{T}_{f h 1}-\bar{T}_{f h 2}}{\ln \frac{\bar{T}_{f h 1}}{\bar{T}_{f h 2}}}
$$

where:

$\mathrm{T}_{\mathrm{f} 01}$ and $\mathrm{T}_{\mathrm{f} 02}=$ higher* temperature point $(\mathrm{K})$

$\mathrm{T}_{\mathrm{fh} 2}$ and $\mathrm{T}_{\mathrm{fh} 2}=$ lower* temperature point $(\mathrm{K})$

*According to the illustration: 1 = higher, 2 = lower.

As for C:

$$
Q_{F C}=\dot{m} c\left(T_{f o}-T_{f h}\right) \frac{\varepsilon_{f}}{\varepsilon_{f}-1}
$$

And the COEFFICIENT OF PERFORMANCE (COP) factor:

$$
\begin{gathered}
\varepsilon_{f}=\frac{\bar{T}_{f o}}{\bar{T}_{f o}-\bar{T}_{f h}} \\
\varepsilon_{f}=\frac{Q_{F C}}{E_{o}}
\end{gathered}
$$

where:

$\overline{\mathbf{T}}_{\mathrm{fo}}=$ average temperature of outbound water $(\mathrm{K})$,

$\overline{\mathrm{T}}_{\mathrm{ff}}=$ average temperature of liquid routed to the heat-pump (K). Also:

$\mathrm{Q}_{\mathrm{FC}}=$ useful thermal energy $(\mathrm{J})$,

$\mathrm{E}_{\mathrm{o}}=$ energy used to maintain system operation $(\mathrm{J})$.

The actual $\varepsilon_{\mathrm{fv}}$ is lower than the COP value:

$$
\varepsilon_{f v}=\delta \varepsilon_{f}
$$

Where $\delta$ is the correction factor (when used for actual calculations, according to literature, its value should be 0,4 for safety reasons).

When we talk about heat-pumping extraction, the question always pops up about how effectively the renewable energy (in our case, the geothermal heat's post-cooling) is used by the heatpumping method. The answer appears if we compare heatpumping with traditional (f.e. natural gas-based) heat production (Büki, 2013).

For a heat-pump, the required electricity $(\mathrm{P})$ for extracting $\mathrm{Q}$ heat:

$$
P=\frac{Q}{\bar{\varepsilon}_{f}}
$$

and its primer energy requirement, f.e. natural gas usage:

$$
G_{f g}=\frac{P}{\eta_{E}}=\frac{Q}{\bar{\varepsilon}_{f} \eta_{E}}
$$

where $\varepsilon \mathrm{f}=\mathrm{Q} / \mathrm{P}$ is the COP factor of the electric heat-pump, $\eta \mathrm{E}=\mathrm{P} / \mathrm{Q}_{\mathrm{fg}}$ is the efficiency level of producing the required electricity $(\mathrm{P})$ (disregarding the losses of heat-pumping).

As we can see above, using heat-pumping before refilling or unloading the thermal water into some water body, we can acquire $60-80 \%$ of the energy that we get at the direct usage. In a proper calculation, this energy, and the operation costs of the heat-pump have to be pitted against the costs of a new well-pair, or the enviro-pressure taxes in case of unloading. In places where refilling can be done without a hitch, using the direct heat production can be competitive, but using energy from renewable sources serves sustainability best.

\section{Summary}

In our article we analyzed the winter heating in greenhouses and used for heating fuels and technologies on the basis of the advantages and disadvantages, and examined the capital and operating costs, and the cost of each unit of energy supply 
systems. We investigated the thermal energy required for that has been used the possibility of heating water heat pump, its advantages and disadvantages

\section{References}

[1] Ádám B. - Tóth L.: 2010 Fütésre használt termálvizek visszasajtolás előtti hőszivattyúzása Mezőgazdasági Technika, Gödöllő, 52. évf. 6.sz. 2-5p. ISSN 00261890

[2] Ádám B.-Tóth L.: 2011 Heat recovery from thermal waters used for heating by heatpump before back-injection, Synergy in the Technical Development of Agriculture and Food Industry (Synergy2011) Gödöll1, Hungary, 9-15. October 2011. 4 p. Disk ISBN: 978-963-269-250-0 http://synergy.szie.hu/hun/news.php [3] ANSI/ASAE EP 406.4 (2003) Standard: heating, ventilation and cooling greenhouses. American Society of Agricultural Engineers, MI, USA

[4] Badger, P.C., and P. Fransham. 2006. Use of mobile fast pyrolysis plants to densify biomass and reduce biomass handling costs - A preliminary assessment. Biomass Bioenergy 30:321325 .

[5] Bai A. et. al. : 2002 Biomassza felhasználása. Szaktudás Kiadó Ház Budapest

[6] Beke J.: 2000. Műszaki hőtan mérnököknek. Mezőgazdasági Szaktudás Kiadó, Budapest. ISBN: 963-356-317-8 pp: 294-317

[7] Büki G.: 2010 Megújuló energiák hasznosítása Magyar Tudományos Akadémia Köztestületi Stratégiai Programok, Budapest, 1-79 p. ISBN 978-963-508-599-6

[8] Büki G.: Megújuló energiák hasznosításának helyzete és egy jövőképe. Magyar Energetika 2010/1.

[9] Csikai M.: - Nagygál J.: 2007 Termálenergia-fejlesztési projektrendszer a Dél-Alföldi régióban, Projektkoncepció 20072013,

[10] Frank P. Incorporeal; David P. De Witt (1990). Fundamentals of Heat and Mass Transfer (3rd ed.). John Wiley \& Sons. p. 2. ISBN 0-471-51729-1.

[11] Hajdú J., Bak J., Pecznik P., Tóvári P.: 2007 A mezőgazdasági üzemek átlagos hőigényének és effektív hőenergia termelésének meghatározásához müszaki-tervezési útmutató 78/2007. (VII. 30) FVM rendelet 2.§. e) és g) pont

[12] Holm A., Blodgett L., Jennejohn D. and Gawell K: (2100) International Market Update, Geothermal Energy Association , Geothermal Energy 2010 May.
[13] Horváth B, Marosvölgyi B, Aranyos P, Vágvölgyi A.: 2010 Domestic developments in the mechanisation of the energetics tree plantations MTA AMB XXXIV. Kutatási és fejlesztési Tanácskozás p. 12. (ISBN:978-963-269-165-7)

[14] Láng Zoltán (1999): A zöldség-, dísznövény- és szaporítóanyag-termesztés berendezései és gépei. Mezőgazda kiadó, Budapest. ISBN 9639239267

[15] Madár V., Tóth L.: 2012 Fagázgenerátor üzemü biokiserőmű (CHP) és öntözőberendezés, Mezőgazdasági Technika, 09 Gödöllő

[16] N. S. Barman, S. Ghosh: 2012 Gasification of biomass in a fixed bed downdraft gasifier - A realistic model including tar In: Elsevier, Bioresource Technology 107. sz., p505-511.

[17] Nagy Sándor - Láng Zoltán (1999): A zöldség, dísznövényés szaporítóanyag-termesztés berendezései és gépei. Mezőgazda Kiadó, Budapest. http://www.hik.hu/tankonyvtar/site/books/b56/ch03.html

[18] Nagygál J.: 2005 Energy Centres in the Agriculture and Transportation EUREGA-RES, Debrecen

[19] Nagygál J.: 2007 Termesztőberendezés komplex korszerüsítés az Árpád-Agrár Zrt. Kertészetében, Tanulmány, Szentes. [20] Nagygál J.: 2014 Experiences of the Geothermal Project in Szentes, Hungary IGC Freiburg, Germany

[21] Stróbl A.: 2011 Tanulmány „A várható magyarországi erőmüépítések fontosabb adatainak rendezése közép- és hosszú távra, valamint a MAVIR ZRt. 2011. évi forrásoldali kapacitáselemzéséhez az első, kiinduló változat összeállítása. ETV-ERÖTERV előzetes kapacitáselemzés, Budapest, Május 31, $81 \mathrm{p}$.

[22] Szücs M.: Passzív napenergia-hasznosítás a mezőgazdasági építészetben, Napenergia a mezőgazdaságban /szerk. Farkas I./, Mezőgazda Kiadó, Budapest, 2003, 207-240. p.

[23] Thorhallsson, S. - Ragnarsson, A. (1992): What is geothermal steam. Geothermics, 21. k. 5/6.sz. okt./dec. p. 901915

[24] Tóth L. -Beke J - Sembery P. - Hajdú J.: 2012. The role of biomass in Hungarian energy supply, Hungarian Agricultural Research, Journal of the Ministry of Rural Development Hungary, Vol. 21, Nr. 4. ISSN 1216 4826. 14-19 p.

[25] Tóth L. et al: 2012. Alternatív energiaellátási rendszerek az agrárgazdaságban, Magyar Agrárkamara, Szaktudás Kiadó Ház, Budapest, ISBN 978-615-5224-22-5, 235.p 188-194pp. 208$215 \mathrm{pp}$ 